\title{
Rezerv Opsiyonu Mekanizması ve Kredi İlişkisi“"
}

\author{
Mehmet ALTUNTAŞ**
}

\begin{abstract}
$\ddot{O} \boldsymbol{Z}$
Küresel kriz sonrası gelişmiş ülkelerce tercih edilen genişletici para politikası uygulamaları, risk iştahının yükselmesiyle birlikte finansal piyasalarda ani fon hareketlerinin yaşanmasına neden olmuştur. Bu gelişmeler, fiyat istikrarını sağlama temel hedefi ile hareket eden merkez bankalarını yeni politika arayışlarına yönlendirmiștir. Geleneksel olmayan para politikası araçları çerçevesinde Türkiye Cumhuriyet Merkez Bankası tarafindan geliştirilen araçlardan biri de rezerv opsiyonu mekanizmasıdır. Bu çalışmada 2011: 09 - 2019: 02 dönemine ilişkin Türkiye'de rezerv opsiyonu mekanizması kullanımı ile işletme ve tüketici kredileri arasındaki ilişsi analiz edilmiştir. Hepsăg (2019)'ın gelişstirdiği doğrusal olmayan asimetrik yumuşak geçişli hata düzeltme modeline göre değişkenler arasında uzun dönemli eşbütünleşik iliş̧kiye ulaşılmıştır.
\end{abstract}

Anahtar Kelimeler: Rezerv Opsiyonu Mekanizması, Tüketici Kredileri, İşletme Kredileri

JEL Sinıflandırmast: E4, E5

\section{The Relationship Reserve Option Mechanism and Credit}

\begin{abstract}
Expansionary monetary policies, which were preferably implemented by developed countries after the global crisis, together with increases in risk appetite, caused sudden changes in fund activities in financial markets. As a result of this, central banks whose primary objective is to ensure price stability began to seek new policies. In this regard, the reserve options mechanism is one of the non-traditional monetary policy instruments developed and conducted by the Central Bank of the Republic of Turkey (CBRT). This study aims to analyse and illustrate the relationship between the use of reserve options mechanism in Turkey and working capital and consumer loans from September 2011 to February 2019. In the light of the nonlinear asymmetric smooth transition error correction model developed by Hepsag (2019), the results indicate that there is a long-run cointegration relationship between the variables.
\end{abstract}

Key Words: Reserve Option Mechanism, Consumer Loans, Working Capital Loans.

JEL Classification: E4, E5

\section{GİRIŞ}

Ekonomi literatürü incelendiğinde 1980'lere kadar istihdam ve sürdürülebilir ekonomik büyüme amaçlarını temel alan maliye politikası ağırlıklı bir ekonomi politikası izlendiği; daha sonraları ise para politikasına ağırlık verildiği görülmektedir. 1970’li yıllarda küresel ölçekte yüksek enflasyonist baskıların ortaya çıkması, fiyat istikrarının önemini gündeme getirmiş ve bağımsız merkez

\footnotetext{
* Bu çalışma, Trakya Üniversitesi Sosyal Bilimler Enstitüsü tarafından 2018 yılında yayınlanan "Bağımsız Para Politikası Çerçevesinde Rezerv Opsiyon Mekanizması ve Katsayısının Analizi” isimli doktora tezinden üretilmiştir.

${ }^{* *}$ Dr. Öğr. Üyesi, Nişantaşı Üniversitesi, İktisadi İdari ve Sosyal Bilimler Fakültesi, Ekonomi ve Finans Bölümü, mehmet.altuntas@nisantasi.edu.tr ORCID bilgisi: 0000-0003-2040-3168
} 
bankacılığı tartışmaları ortamında para politikası yoğun bir şekilde kullanılmaya başlanmıştır. Günümüz merkez bankacılığı sisteminde geleneksel para politikası araçları ile birlikte geleneksel nitelikte olmayan araçlar da yoğun olarak kullanılmaya başlanmıştır.

Küresel krizle birlikte fiyat istikrarının sağlandığı çok sayıda ülkede finansal krizlerin çıkışının engellenemediği görülmüştür. Merkez Bankacılığı sisteminde tek amaç olan fiyat istikrarına tek politika aracı olan faiz oranları ile ulaşılmasını gerektiren rejimlerin yetersiz kalması, birden çok amaca ulaşmak için birden çok aracın kullanıldığı esnek politika uygulamalarını gündeme getirmiştir.

2008 Mortgage krizi ile birlikte birçok gelişmiş ve gelişmekte olan ülkenin para ve sermaye piyasaları ile reel sektörü üzerinde önemli etkiler ortaya çımış ve ekonomik istikrarın yeniden kurgulanması noktasında ülke ekonomilerince yeni politika arayışları başlatılmıştır. Bu bağlamda yoğun bir şekilde genişletici para politikası uygulamaları tercih edilmiş ve bu politikalar da bazı ekonomik büyüklükleri olumlu etkilerken bazı büyüklüklerde de çok boyutlu kırılganlıklar meydana getirmiştir.

Küresel finansal krizi izleyen dönemlerde merkez bankalarının para arzını genişletici yöndeki uygulamaları, kısa vadede maksimum getiri sağlama amacıyla hareket eden uluslararası yatırımcıları özellikle gelişmekte olan ülkeler üzerinde hızlı fon transferi yapmaya yönlendirmiştir. İlk etapta döviz kuru üzerinde yüksek seviyede oynaklıklar oluşturan ani nitelikteki bu finansal hareketler, beklentilerin gerçekleştirilememesi yoluyla çok sayıda ekonomik değişken üzerinde olumsuz etkiler meydana getirmiştir.

$\mathrm{Bu}$ çerçevede ekonomi otoriteleri, piyasalarda sürdürülebilir iyileşmelerin sağlanması noktasında geleneksel para politikası araçları ile birlikte geleneksel olmayan araçlar da inşa etmeye başlamışlardır. Türkiye Cumhuriyet Merkez Bankası (TCMB) tarafindan geliştirilen bu geleneksel olmayan para politikası araçlarından biri de Rezerv Opsiyonu Mekanizması (ROM) olmuştur. ROM, sermaye giriş ve çıkışlarındaki aşırı oynaklığın makroekonomik büyüklükler ve finansal istikrar üzerinde oluşturacağı olumsuz etkileri belirli ölçüde sınırlandırmak amacıyla geliştirilen önemli bir para politikası aracı olarak uygulamadaki yerini almıştır.

ROM kapsamında çok sayıda doğrudan ve dolaylı etkinin oluşacağ 1 öngörülmüsștür. Mekanizma ile Türk Lirası yükümlülüklerin döviz cinsinden tesis edilmesi söz konusu olduğu için bankaların daha esnek şartlarda piyasaya kredi sunması beklenmektedir. Çalışmanın literatüre yapacağı katkı, mekanizmanın işletme ve tüketici kredileri üzerinde oluşturacağı etki noktasındadır. Bu çerçevede çalışma giriş ve sonuç kısımları dışında üç kısımdan oluşmaktadır. İlk kısımda ROM'un teorik temelleri ele alınmıştır. İkinci kısımda veri seti ve yöntem açıklanmış ve son kısımda da uygulanan ekonometrik modelin ampirik bulguları belirtilmiştir.

\section{TEORIKK ARKA PLAN}

Ekonomilerin birbirlerine olan bağımlılıklarının sürekli olarak artış gösterdiği günümüz dünyasında farklı ülkelerde ortaya çıkan krizler, domino 
etkisiyle tüm ülkeleri etkisi atına almaktadır. Küresel Finansal Kriz de gelişmiş ve gelişmekte olan birçok ülkeyi etkisi altına alarak ekonomileri yeni politika arayışlarına yönlendirmiştir.

Amerikan Merkez Bankası'nın 2007 yılında faiz oranlarını yükseltmesi, Amerika'da bankaların ödeme gücü düşük kesime kullandırmış oldukları değişken faizli kredilerin geri ödemelerinde zorluklar yaşanmasına neden olmuştur. $\mathrm{Bu}$ çerçevede 2007 yılında ortaya çıkan Mortgage krizi ile birlikte finansal piyasalarda oluşan ortam, 2008 yılında Lehman Brothers Yatırım Bankası'nın iflasını açıklaması ile küresel kriz halini almıştır.

Ekonomi yönetimleri, küresel finans krizinin etkilerini azaltmaya yönelik olarak para ve maliye politikası uygulamaları ve çeşitli finansal düzenlemelerle ekonomik aktiviteleri canlandırmaya çalışmışlardır. Bu çerçevede krizin ilk aşamalarında ülkeler; mevduat garantileri, yurt içi likidite kolaylığı, bankaların yeniden sermayelendirilmesi, bankaların borçlanmalarına kamu garantisi, kredi garantileri, kamulaştırma, döviz kuru müdahaleleri, politika faizi değişikliği, zorunlu karşılık oranlarında değişiklik, SWAP kanalı, IMF destekleri ve genişletici maliye politikası uygulamaları gibi geleneksel yöntemlere başvurmuşlardır (Vural, 2013: 9).

Söz konusu geleneksel politika uygulamalarının sadece fiyat istikrarı amacı ile şekillendirilmiş olması, küresel kriz sürecinde söz konusu araçların yetersiz kalmasına neden olmuştur. Küresel kriz ile birlikte fiyat istikrarının yanında finansal istikrarın da öneminin ortaya çıkması, birden çok amaca ulaşmak için birden çok aracın kullanıldığı esnek politika uygulaması arayışlarını gündeme getirmiştir.

Para politikası, toplam talebi genişletici veya daraltıcı bir ekonomi politikası olarak eski dönemlerden beri kullanılan bir politika bileşeni olmakla birlikte para politikası eksenindeki amaçlar, dönemler itibariyle farklılıklar göstermiştir. Bu farklılaşmada küresel nitelikte ekonomik krizlerin yaşanması, çok sayıda bölgeyi etkileyen savaşların yaşanması, küreselleşme eğilimlerine bağlı olarak uluslararası ticaretin gelişmesi ve mevzuatsal alanda yaşanan gelişmeler etkili olmuştur (Serin, 1987: 8). 2008 Küresel Finansal Krizi de farklılaşmanın yaşandığ 1 önemli kırılma dönemlerinden biridir.

Küresel krizi izleyen dönemlerde risk iştahının artış göstermesi, sermayenin küresel ölçekte çok daha hızlı hareket etmeye başlaması ve buna bağlı olarak fiyat istikrarı ile birlikte finansal istikrarı sağlamaya yönelik politikaların ön plana çıkartılmak istenmesi, göreceli olarak iyi performansa sahip makroekonomik değişkenler üzerinde olumsuz etkiler oluşturmayacak yeni politika araçlarının geliştirilmesi ihtiyacını gündeme getirmiştir.

İhtiyaç duyulması halinde koridor faizinin aşağı ve yukarı yönlü asimetrik hale getirilmesi ve aktif likidite yönetimi ile anlık değişen finansal koşullara hızlı tepki verebilir hale getirilen faiz politikasının yanında karşılıklar politikası finansal istikrarı korumak amacıyla etkin bir şekilde kullanılmaya başlamıştır (Böcüoğlu, 2005: 1). Karş11ıklar politikası kapsamında zorunlu karşılıklara faiz ödenmesi ve farklı vadelerde farklı oranların belirlenmesi yoluyla çok oranlı bir sistem tercih 
edilirken, geliştirilen en önemli yenilik zorunlu karşıllklara farklı bir boyut kazandıran ROM sistemi olmuştur.

ROM, bankalarca Türk lirası olarak ödenecek zorunlu karşı1ıkların Merkez Bankasınca önceden belirlenmiş orandaki yüzdelik bir kısmını döviz veya altın cinsinden tesis edebilmesine olanak sağlayan karşılıklar politikası temelli bir araçtır. Geleneksel olmayan bu para politikası aracının uygulanması sürecinde Rezerv Opsiyonu Oranı ve Rezerv Opsiyonu Katsayısı önem arz eden iki kavramdır. ROM'un hangi oranda veya hangi dilimler kapsaminda kullanılabileceğini ortaya koyan orana Rezerv Opsiyonu Oranı denilmektedir. Her bir dilim dahilinde ulusal para zorunlu karşılık başına tesis edilebilecek döviz veya altın karşılığını belirleyen katsayılara da Rezerv Opsiyonu Katsayısı (ROK) denilmektedir (Alper vd., 2012: 9).

ROM, 2011 yılının son çeyreği ve 2012 y1lı içerisinde yapılan düzenlemelerle tedrici bir yapıda kurularak işlerlik kazanan bir sistemdir. Her bir kurul toplantısında ROM'un TCMB döviz rezervlerinde ve para piyasasında oluşturacağı etkilerin öngörüsü hazırlanarak dilimler ve/veya katsayılar çerçevesinde yeni düzenlemelere gidilmiştir.

ROM, karşılıklar politikası kapsamındaki ulusal para yükümlülüklerinin bir kısmının sadece döviz cinsinden yerine getirilmesiyle değil aynı zamanda altın ve işlenmiş veya hurda altın cinsinden tesis edilmesi şeklinde de kullanılabilmektedir. Mekanizma kapsamındaki altın opsiyonlarıyla ilgili dilim ve katsayılar da TCMB tarafindan ilan edilmektedir.

Başlangıç aşamasında Türk Lirası zorunlu karşılıkların belirli bir kısmının bire bir katsayı üzerinden döviz ve hemen arkasından da altın olarak tesis edilebilmesine imkan tanınmıştır. Bununla birlikte ilk zamanlarda rezerv opsiyonu dilimlerinin artırılması ön planda tutulurken, ilerleyen zamanlarda katsayılar da revize edilmeye başlanmıştır. 2012 yılının Ağustos ayında alınan kurul kararıyla Türk Lirası zorunlu karşı1lıları döviz olarak tesis edebilme imkanı yüzde 60'a, altın olarak tesis edebilme imkanı ise yüzde 30'a yükseltilmiştir. Ekonomik alanda yaşanan gelişmeler takip edilerek 2018 yılının Ağustos ayında ROM kapsamındaki döviz imkanı oranı üst sınırı yüzde 40'a indirilmiştir'.

Küresel Finansal Kriz sonrası para otoritelerinin genişletici politika uygulamalarına başvurması, kısa vadede yüksek getiri elde etmek isteyen küresel yatırımcıları ülkeler üzerinde hızlı para transferleri yapmaya yönlendirmiştir. Uluslararası piyasalarda yaşanan bu ani finansal hareketler, özellikle döviz kuru üzerinde yüksek seviyede volatilite meydana getirdiği için beklentilerin şekillendirilememesi yoluyla çok sayıda ekonomik büyüklük üzerinde olumsuz etkiler oluşturmuştur.

Fiyat istikrarının yanı sıra finansal istikrarın da ön planda tutulduğu yeni politika arayışı süreçlerinde her yeni araca çok sayıda amaç yüklenmiştir. Bu kapsamda ROM'a da; kısa vadeli sermaye akımlarının piyasalarda meydana getireceği oynaklıkları azaltmak, TCMB'nin brüt döviz rezervlerini artırmak,

${ }^{1} \mathrm{Bu}$ bilgiler, TCMB tarafindan ilan edilen basın bültenlerinden derlenmiştir. 
bankalara kendi likiditelerini oluşturma noktasında esneklik sağlamak, kredilerin sermaye hareketliliğine olan duyarlılığını azaltmak, bankalara kendi likidite optimizasyonlarını gerçekleştirebilmeleri için kolaylıklar sunmak ve para politikası uygulamalarındaki sadeleştirme süreçlerine destek oluşturmak şeklinde hedefler yüklenmiştir (TCMB, 2012: 5).

Mekanizma ile Türk Lirası zorunlu karşılıklar için bankalara döviz ve altın tesis imkanının sunulması, temel olarak TCMB'nin brüt döviz rezervlerinin artmasını beraberinde getirmiştir. ROM kapsamındaki yabancı para ve altınların TCMB tarafından satın alınmamış olup söz konusu varlıkların bankacılık sektöründeki finansal oyunculara ait olması, merkez bankasının net döviz rezervleri yerine brüt döviz rezervlerini etkilemektedir.

Söz konusu bu geleneksel olmayan aracın net değil de brüt döviz rezervlerine etki ediyor olması mekanizmanın sisteme fayda sağlamadığı anlamına gelmemelidir. Sermaye hareketlerindeki aşırı oynaklıklar, özel sektörde faaliyet gösteren kuruluşların finansal tablolarını ve borç ödeme kapasitelerini önemli ölçüde olumsuz etkileyebilmektedir. Bu bağlamda yabancı para rezervlerinin büyük ölçüde özel sektörün kontrolünde bulunması ve sektör temsilcilerinin de ilgili rezervleri uygun şekilde kullanabilmesi piyasadaki etkinliği artırarak daha sağl1klı bir finansal sistemde faaliyet gösterilmesine destek olacaktır (Alper vd., 2012: 18).

Temel işlevleri gereği bankalar, fon fazlası olan iktisadi karar birimlerinden topladıkları mevduatları, fon ihtiyacı olan birimlere kredi olarak sunmaktadırlar. Mevduatların yetersiz kalması durumunda iç veya dış kaynaklardan borçlanacak olan bankalar için ROM, diğer birçok yönteme başvurmadan daha uygun şartlarda Türk Lirası likidite sağlama noktasında önem arz etmektedir.

Mekanizma, bir yandan fon yönetimi konusunda bankalara esneklik sunarken bir yandan da bankaların piyasaya sunacakları kredi hacmini genişletecektir. Ayrıca TCMB'nin katsayıyı düşük seviyelerde belirlemesi, ROM kullanımını daha cazip hale getirecek ve bankaların diğer kaynaklara olan talebini de büyük ölçüde azaltacaktır (Büyüksaraç ve Özel, 2012, 5).

Diğer taraftan bankalardaki döviz rezervlerinin bir miktarının Türk Lirası zorunlu karş1lık yükümlülüklerinin yerine getirilmesi noktasında merkez bankasına tesis edilmesinin ani finansal hareketleri belirli ölçüde azaltarak ekonomik güvenin oluşturulmasına katkı sağlaması da istenmiştir.

Bankacılılık kesiminin mekanizmayı hangi yoğunlukta kullanacağı, ilgili tesis dönemlerindeki ekonomik konjonktür doğrultusunda yapılacak fayda maliyet analizlerine göre şekillenmektedir. Yabanc1 sermaye girişlerinin yoğun olduğu dönemlerde göreceli olarak ulusal para kaynak maliyeti döviz kaynak maliyetine göre daha yükssek olabileceği için ROM, bu dönemlerde yüksek dilimlerde dahi kullanılabilmektedir. Yabancı sermaye çıkışlarının yoğun olduğu dönemlerde ise, göreceli olarak ulusal para kaynak maliyeti daha avantajlı olabileceği için bankalar mekanizmayı daha düşük seviyelerde kullanacaklardır.

Finansal piyasalarda bu mekanizmanın daha fazla kullanılmak istenmesi ve TCMB'nin de brüt döviz rezervlerini artırmak istemesi durumunda mekanizmaya 
yeni bir dilim eklenebilecek ya da katsayı yükseltilebilecektir. Piyasanın döviz gereksinimi olması durumunda ise TCMB, bir dilimi iptal ederek veya katsayı1 aşağ 1 yönlü revize ederek piyasaya döviz likiditesi sağlayabilecektir. Bu çerçevede TCMB, yabanc1 sermaye hareketlerinin meydana getireceği etkileri dengeleyebilmek adına mekanizmada güncellemeler yapabilecektir (Gürkan Yay, 2015: 270).

2008 küresel krizi sonrasında kısa vadeli sermaye hareketlerinin gelişmekte olan ülkelere doğru yönelmiş olması, döviz cinsinden borçlanma olanaklarını daha uygun hale getirmiştir. Söz konusu ortamda TL zorunlu karşılıkları rezerv opsiyonu katsayısına göre olabilecek optimal maliyetle tutmak isteyen bankalar, TL yükümlülüklerini finansal piyasalardaki en düşük faiz oranlarına sahip olan döviz ve altın cinsinden tutabilmektedirler (Tuna vd., 2015: 227). Otomatik dengeleyici bir mekanizma olarak tasarlanan ROM'un güçlü sermaye giriş ve çıkışları yaşanan dönemlerde piyasadaki döviz likiditesini etkilemek suretiyle döviz kuru volatilitesini azaltması öngörülmektedir. Sonuç olarak ROM'un ani sermaye hareketleri nedeniyle ortaya çıkan kur oynaklıklarının giderilmesinde etkin bir politika aracı olduğu düşünülmektedir (Oduncu vd., 2013: 50).

\section{VERI SETI VE YÖNTEM}

Çalışmada 2011:09 - 2019:02 dönemlerine ait Türkiye'de ROM kullanımı ile işletme kredileri (ISL) ve tüketici kredileri (TKT) arasındaki ilişki analiz edilmiştir. Veriler aylık olarak ele alınmış olup, ROM değişkenine TCMB elektronik veri dağıtım sistemi (EVDS) üzerinden, işletme kredileri ve tüketici kredileri değişkenlerine ise Bankacılık Düzenleme ve Denetleme Kurumu veri tabanından ulaşılmıştır. Doğal logaritması alınmış değişkenler modele dahil edilmiş ve bilgisayar uygulaması için E-views 10.0 ve WinRats 8.0 programları kullanılmıştır.

Engle ve Granger (1987), zaman serilerinin kendi içerisindeki uzun dönemli ilişkisini ortaya koyabilmek için eşbütünleşme testlerini ekonometri literatürüne kazandırmışlardır. Burada bahsedilen eşbütünleşme testlerinin temelinde düzeyde durağan dışı olan zaman serilerinin belli başlı işlemler sonucunda durağan hale gelebileceği varsayımı bulunmaktadır. Aynı zamanda yine Engle ve Granger (1987) tarafından ortaya atılan hata düzeltme modeli ile kısa dönemdeki dengesizliğin uzun dönemde dengeye gelebileceği varsayılmaktadır. Buradaki bahsedilen varsayımın gerçekleşmesi doğrusal bir biçimde meydana gelmektedir.

Fakat ekonominin içerisinde zaman serileri arasındaki ilişkilere bakılarak uzun dönem dengesi aranırken doğrusal olmayan davranışlarla karşılaşmak mümkündür. Söz konusu değişkenler, doğrusal olmayan davranışlar gösteren bir ekonomik ilişki içerisinde ise Engle ve Granger (1987) tarafından geliştirilen eşbütünleşme testleri kullanıldı̆̆ 1 takdirde anlamlı olmayan sonuçlar ile karşılaşılabilmektedir. Başka bir ifade ile eşbütünleşik ilişkinin bulunmadığını belirten sıfır hipotezini reddedememe yönünde eğilim gösteren sonuçlar verebilmektedir. Karşılaşılan bu durum Engle ve Granger (1987) eşbütünleşme testlerinin güçsüzlügünün bir göstergesi olarak görülmektedir. 
Yapılan bu çalışmada eşbütünleşik ilişki aranırken doğrusal dış1lığı göz önünde bulunduran ve Hepsağ (2019) tarafindan ekonometri literatürüne kazandırılan doğrusal olmayan eşbütünleşme testi kullanılmıştır. Aynı zamanda Hepsağ (2019) tarafından geliştirilen bu testler de Engle - Granger testlerindeki gibi kalıntılara dayanan testlerdir ve iki aşamalı bir yöntemi temel almaktadır.

Öncelikli olarak aşağıdaki uzun dönem modeli tahmin edilerek bu modele ait kalıntılar elde edilecektir:

$$
y_{t}=\beta x_{t}+u_{t}
$$

(1) no'lu denklemde yer alan modelin kalıntılarına ulaşıldıktan sonra ikinci aşamada bu kalıntıların doğrusal olmayan asimetrik üssel yumuşak geçişli otoregresif (AESTAR) süreç izlediği varsayllarak, (2) no'lu gösterimde verilen doğrusal olmayan asimetrik üssel yumuşak geçişli otoregresif hata düzeltme modeli (AESTAR-ECM) dikkate alınmaktadır (Hepsăg, 2019: 3):

$$
\Delta y_{t}=G_{t}\left(\theta_{1}, u_{t-1}\right)\left\{S_{t}\left(\theta_{2}, u_{t-1}\right) \gamma_{1}+\left(1-S_{t}\left(\theta_{2}, u_{t-1}\right)\right) \gamma_{2}\right\} u_{t-1}+\psi^{\prime} \Delta \mathbf{x}_{\mathbf{t}}+\sum_{i=1}^{p} \boldsymbol{\omega}_{\mathrm{i}}^{\prime} \Delta \mathbf{z}_{\mathbf{t}-\mathbf{i}}+\varepsilon_{t}
$$

(2) no'lu doğrusal olmayan hata düzeltme modelinde yer alan $z_{t}=$ $\left(y_{t}, x^{\prime}{ }_{t}\right)^{\prime}$, birinci mertebeden durağan $(I(1)) n \times 1$ boyutlu değişkenlerdir.

Hepsağ (2019), (2) no'lu gösterimde sunulan doğrusal olmayan hata düzeltme modelinden yola çıkılarak eşbütünleşik ilişkisinin sınanmasında $H_{0}: \theta_{1}=0$ sıfir hipotezinin $H_{1}: \theta_{1}>0$ alternatif hipotezine karşı test edilmesini önermektedir. Ancak Kapetanios vd. (2006) tarafindan önerilen ve (2) no'lu gösterimde yer alan doğrusal olmayan hata düzeltme modelinde bulunan $\theta_{2}, \gamma_{1}$ ve $\gamma_{2}$ parametrelerinin sifir hipotezinde tanımlı olmamasından dolay $\theta_{1}=0$ sifir hipotezi doğrudan sınanamamaktadır. Bu sorun ile mücadele etmek amaciyla Hepsağ (2019) tarafından önerildiği haliyle (2) no'lu doğrusal olmayan hata düzeltme modeline birinci mertebeden Taylor açılımı uygulanabilmektedir. $\theta_{1}=0$ ve $\theta_{2}=0$ etrafinda birinci mertebeden Taylor açılımı sonucunda aşağıdaki yardımc1 regresyon modeline ulaşılabilmektedir.

$$
\Delta y_{t}=\phi_{1} \hat{u}_{t-1}^{3}+\phi_{2} \hat{u}_{t-1}^{4}+\psi^{\prime} \Delta \mathbf{x}_{\mathbf{t}}+\sum_{i=1}^{p} \boldsymbol{\omega}_{\mathbf{i}}^{\prime} \Delta \mathbf{z}_{\mathbf{t}-\mathbf{i}}+v_{t}
$$

(3) no'lu yardımcı regresyon modeli için $\varphi_{1}=\varphi_{2}=0$ sıfır hipotezi oluşturulmakta ve $\varphi_{1} \neq \varphi_{2} \neq 0$ alternatif hipotezine karşı test edilmektedir ve katsayılara getirilen kısıtlara dayalı olarak $F_{A N E C}$ test istatistiği hesaplanmaktadır. Hesaplanan $F_{A N E C}$ test istatistiğinin Hepsăg (2019) tarafindan elde edilen kritik değerlerden büyük olması durumunda eşbütünleşmenin olmadığını ifade eden sıfır hipotezi, doğrusal olmayan asimetrik ESTAR eşbütünleşmenin varlığına karş1 reddedilmektedir.

Hepsağ (2019) tarafindan belirtildiği haliyle bu eşbütünleşme yardımcı regresyon modellerinde sabit terim ve/veya trend gibi deterministik bileşenlerin yer almasının yerine analizde kullanılan değişkenler; ham biçimde, ortalamadan 
arındırılmış şekilde, ortalamadan ve trendden arındırılmış şekilde kullanılabilmektedir.

\section{AMPIRIKK BULGULAR}

Çalışmaya konu olan değişkenler arasındaki uzun dönemli ilişkiyi tespit etmek amacı ile analize geçilmiştir. Zaman serileri arasındaki eşbütünleşik ilişkiyi belirlemeden önce serilerin birim köklü olup olmadıklarına bakılarak durağanlık mertebeleri belirlenmektedir. Bundan dolayı serilerin durağanlık mertebelerinin tespiti için Genişletilmiş Dickey-Fuller (ADF)) birim kök testi uygulanmış ve sonuçlar aşağıdaki Tablo 1'de verilmiştir:

Tablo 1: Değişkenlere Ait ADF Birim Kök Testi Sonuçları

\begin{tabular}{|c|c|c|}
\hline \multicolumn{3}{|c|}{ Genişletilmiş Dickey-Fuller (ADF) Birim Kök Testi } \\
\hline Değişkenler & Gecikme Uzunluğu & t-İstatistiği \\
\hline LNROM & 8 & -1.134133 \\
\hline LNISL & 0 & -2.680829 \\
\hline LNTKT & 1 & -1.948434 \\
\hline$\Delta$ LNROM & 7 & $-3.140244 *$ \\
\hline$\Delta$ LNISL & 0 & $-7.952325^{*}$ \\
\hline$\Delta$ LNTKT & 0 & $-3.375407 *$ \\
\hline
\end{tabular}

* \% 5 anlamlılık düzeyinde sıfır hipotezi olan birim kökün varlığının reddedildiğini göstermektedir. Gecikme uzunlukları Akaike Bilgi Kriteri (AIC) kullanılarak belirlenmiştir. " $\Delta$ ” serilerin 1. farkının alındığını belirtmektedir.

Tablo 1'in sonuçlarına göre analize konu olan 3 değişkenin de birinci farkında durağan yani $\mathrm{I}(1)$ değişkenler olduğu görülmektedir. Bu doğrultuda yöntem kısmında bahsedilen Hepsağ (2019) doğrusal olmayan asimetrik üssel yumuşak geçişli hata düzeltme modelini temel alan eşbütünleşme testine geçilmiştir. İktisat literatürüne uygun bir şekilde belirlenen değişkenler arasındaki ilişki, işletme kredilerinin bağımlı değişken, ROM'un bağımsız değişken ve tüketici kredilerinin bağımlı değişken, ROM'un bağımsız değişken olduğu iki farklı model kurulmuştur. Testin uygulanmasında özellikle ortalamadan ve trendden arındırılmış seriler dikkate alınmış ve sonuçlar tablo 2'de ortaya konulmuştur:

Tablo 2: Hepsağ Eşbütünleşme Testi Sonuçları

\begin{tabular}{ccc}
\hline Bağımlı Değişken (LNISL) & Test İstatistik $\left(\boldsymbol{F}_{\text {ANEC }, t}\right)$ & Gecikme Uzunluğu \\
\hline LNROM & $6.72813^{* *}$ & 3 \\
\hline Bağımlı Değişken (LNTKT) & Test İstatistik $\left(\boldsymbol{F}_{\text {ANEC,t }}\right)$ & Gecikme Uzunluğu \\
\hline LNROM & $8.32558^{*}$ & 1 \\
\hline \hline
\end{tabular}

*\% 5**\% 10 anlamlılık düzeyinde eşbütünleşik ilişki olmadığını belirten sıfır hipotezinin reddedilemediği görülmektedir. Maksimum gecikme uzunluğu Schwert (1989)' e göre belirlenmiştir.

Tablo 2'nin sonuçlarına göre hem işletme kredileri ile ROM arasında hem de tüketici kredileri ile ROM arasında uzun dönemli eşbütünleşik ilişki tespit edilmiştir. Uzun dönem modeli aşağıdaki tablo 3'de gösterilmektedir. 
Tablo 3: Uzun Dönem Sonuçları

\begin{tabular}{ccc}
\hline Bağımlı Değişken (LNISL) & Katsayı & t-istatistik \\
\hline LNROM & 1.2061 & $12.81564^{*}$ \\
\hline Bağımlı Değişken (LNTKT) & Katsayı & t-istatistik \\
\hline LNROM & 0.6917 & $10.67503^{*}$ \\
\hline \hline
\end{tabular}

*\% 5 anlamll1ık düzeyinde istatistiksel olarak anlamllı̆̆ 1 ifade etmektedir.

Tablo 3'de gösterilen uzun dönem modeline bakılacak olunursa, ROM'un işletme kredileri üzerinde uzun dönemde anlamlı ve pozitif bir değişken olduğu sonucuna ulaşılmaktadır. Aynı sonuçlar tüketici kredilerinde de görülmektedir. ROM'da meydana gelecek \% 1'lik bir artış, işletme kredilerini \% 1.2061 oranında artırmaktadır. Ayrıca ROM'da meydana gelecek \% 1'lik bir artış, tüketici kredilerini \% 0.6917 oranında artırmaktadır. Bu sonuçların ardından hata düzeltme modeli üzerinden kısa dönemli nedensellik analizi yapılarak tablo 4'de gösterilmiştir;

Tablo 4: Kısa Dönem Nedensellik Sonuçları

\begin{tabular}{lcc}
\hline & $\mathbf{F}(4,77)$ & Gecikme Uzunluğu \\
\hline$\Delta L N R O M+\Delta L N I S L$ & 1.35386 & 3 \\
\hline$\Delta L N R O M+\Delta L N T K$ & $\mathbf{F}(2,83)$ & Gecikme Uzunluğu \\
\hline \hline
\end{tabular}

Yukarıdaki sonuçlara göre \% 5 anlamlılık düzeyinde istatistiksel olarak anlamlılığa rastlanılmamıştır.

ROM, k1sa dönemde işletme kredilerinin bir nedeni olarak görülmemekte ve birbirlerini etkilememektedir. Aynı zamanda ROM, kısa dönemde tüketici kredilerinin de bir nedeni olarak görülmemekte ve birbirlerini etkilememektedir. Burada kısa dönemli bir nedensellik ilişkisi tespit edilememiştir.

\section{SONUÇ}

Önemli ölçüde fiyat istikrarını sağalamaya yönelik olarak tasarlanmış geleneksel para politikası araçlarının küresel krizin etkilerini giderebilme noktasında yetersiz kalması, finansal istikrarı sağalama amacını da içinde barındıran yeni para politikası araçlarının geliştirilmesi ihtiyacını gündeme getirmiştir. Bu çerçevede diğer araçlara kıyasla sistemi daha etkin hale getirecek ve kendi optimizasyonlarını sağalama noktasında bankalara olanak tanıyacak bir araç olarak ROM geliştirilmiştir. ROM'un diğer birçok araca olan ihtiyacı azaltacak şekilde otomatik dengeleyici bir yapıda kurulmuş olması, araca özel bir nitelik kazandırmıștır.

Mekanizma ile Türk Lirası zorunlu karşılıkların döviz ve altın cinsinden tesis edilmesine imkan verilmesi, bankaların piyasaya sunabilecekleri kredi miktarı noktasından daha esnek çalışmalarını sağlamıştır. $\mathrm{Bu}$ bağlamda zorunlu karşı1ıkların bir kısmının döviz ve altın olarak ödenmesi sonucunda bankaların rezervlerinde kalan ulusal paraların büyük ölçüde işletme ve tüketici kredileri yoluyla piyasaya çıkacağı öngörülmüş̧ür.

Dünya genelindeki birçok merkez bankasında olduğu gibi TCMB de sadeleşme sürecini sürdürülebilir bir yapıda sağlamak istemektedir. Fakat çok sayıda para politikası aracının varlığı ve her bir aracın da kendi içerisinde alt 
araçlarının söz konusu olması, sadeleşme sürecini zora sokmaktadır. Bu çerçevede mekanizmanın sadeleşme sürecinde de sisteme destek oluşturabileceği önem arz etmektedir.

Çalışmada 2011:09 ile 2019:02 dönemleri arasını kapsayan işletme kredileri ve ROM arasında uzun dönemli eşbütünleşik ilişkiye rastlanılmıştır. Ayrıca aynı dönemlerde tüketici kredileri ile ROM arasında da uzun dönemli eşbütünleşik ilişki gözlemlenmiştir. Bu durum uzun dönemde ROM'daki bir değişimin işletme kredilerini ve tüketici kredilerini etkileyeceğine işaret etmektedir. Yapılan analiz sonucunda ROM'da meydana gelen \% 1'lik bir artışın işletme kredilerini \% 1.2061 oranında artırdığına ulaşılırken aynı zamanda ROM'da meydana gelen \% 1'lik bir artışın tüketici kredilerini \% 0.6917 oranında artırdığ 1 belirlenmiştir. Son olarak ise kısa dönemli ilişki incelenmiş ve hem ROM ile işletme kredileri arasında hem de ROM ile tüketici kredileri arasında nedensellik ilişkisine rastlanılmamıştır.

\section{KAYNAKÇ.A}

Alper, K., Kara, H. ve Yörükoğlu, M. (2012), "Sermaye Akımlarının Etkilerini Yumuşatmaya Yönelik Yeni Bir Para Politikası Aracı: Rezerv Opsiyonu Mekanizması", İktisat ve Toplum Dergisi, Say1 25, s. 9 - 19.

Böcüoğlu M. E. (2015), Rezerv Opsiyon Mekanizmasının Banka Davranışlarına Etkisi, Uzmanlık Yeterlilik Tezi, Türkiye Cumhuriyet Merkez Bankası, Ankara.

Büyüksaraç, D. ve Özel, Ö. (2012), Rezerv Opsiyonu Mekanizması ve Optimal Rezerv Opsiyonu Katsayılarının Hesaplanması, Türkiye Cumhuriyet Merkez Bankası Çalışma Tebliği, Ankara: Sayı 12/32.

Dickey, D. A. ve Fuller, W. A. (1979), "Distribution of the Estimators for Autoregressive Time Series with a Unit Root, Journal of the American Statistical Association”, 74 (366), s. 427 - 431.

Engle, R. F. ve Granger, C. W. J. (1987), "Cointegration and Error Correction: Representation, Estimation, and Testing”. Econometrica, 55 (2), s. 251 - 276.

Gürkan Yay, G. (2015), Para ve Finans Teori Politika, İstanbul: İstanbul Bilgi Üniversitesi Yayınları.

Hepsag, A. (2019), Testing for Cointegration in Nonlinear Asymmetric Smooth Transition Error Correction Models, Communications in Statistics, Simulation and Computation. https://doi.org/10.1080/03610918.2018.1559927, (Erişim Tarihi: 23.03.2018).

Kapetanios, G., Shin, Y. ve Snell, A. (2006), "Testing for Cointegration in Nonlinear Smooth Transition Error Correction Models". Econometric Theory, 22 (2), s. 279-303.

Oduncu, A., Ermişoğlu, E. ve Akçelik, Y. (2013), "Merkez Bankasının Yeni Enstrümanı Rezerv Opsiyonu Mekanizması ve Kur Oynaklığı”, Bankacılar Dergisi, Sayı: 86, s. 43 - 53.

Schwert, G. W. (1989), "Tests for Unit Roots: A Monte Carlo Investigation”, Journal of Business \& Economic Statistics, 7 (2), s. 147 - 159.

Serin, V. (1987), Para Politikası, İstanbul: Marmara Üniversitesi Yayınları, Yayın No: 440.

TCMB (2012), Aylık Bülten, Say1: 28.

Tuna, A., Öner, S. ve Öner, H. (2015), "Rezerv Opsiyonu Mekanizmasının Optimal Kullanımı ve Türk Bankacılık Sektörü Açısından Maliyet Analizi”, Atatürk Üniversitesi İktisadi ve İdari Bilimler Dergisi, 29 (2), s. 219 - 232.

Vural, U. (2013), Geleneksel Olmayan Para Politikalarının Yükselişi, Uzmanlık Yeterlilik Tezi, Türkiye Cumhuriyet Merkez Bankası, Ankara.

\section{SUMMARY}

The expansionary monetary policy implementations preferred by developed countries after the global crisis caused sudden fund movements in financial markets with the increase of risk appetite. These developments have led 
central banks, which act with the main objective of ensuring price stability, to seek new policies. Within the framework of unconventional monetary policy instruments, one of the tools developed by the Central Bank of the Republic of Turkey is the reserve option mechanism.

Together with price stability, each new organ has many objectives in the new policy structuring processes, in which financial stability is significant. Within this context, ROM goals are defined as reducing the volatility of short-term capital movements in the markets, increasing the gross foreign exchange reserves of the CBRT, providing flexibility to banks to create their own liquidity, reducing the sensitivity of loans to capital mobility, providing liquidity optimizations to banks and supporting the simplification processe. As is seen, there are many direct and indirect effects in the ROM. The mechanism is expected to offer loans to the market under more flexible conditions, as Turkish Lira liabilities are to be established in foreign currency. Within this context, the impact of the mechanism on working capital loans and consumer loans reveals the basic scope of the study.

In this study, the relationship between the use of the reserve option mechanism(ROM) in the 2011: 09-2019: 02 period and working capital loans (WCL) and consumer loans (CL) in Turkey was analysed. Nonlinear cointegration test which was introduced to econometric literature by Hepsağ (2019), which considers the linearity while searching for the cointegrated relationship, was used. These tests, also developed by Hepsağ (2019), are based on residues as in the Engle - Granger tests and are based on a two - stage method.

The result of the analysis showed that there is a long-term co-operative relationship between business loans and reserve option mechanism as well as between consumer loans and reserve option mechanism. It has been concluded that the reserve option mechanism is a significant and positive variable in the long term on the operational loans. The same results are seen in consumer loans. An increase of $1 \%$ in the reserve option mechanism increases operating loans by $1.2061 \%$. Besides, a $1 \%$ increase in the reserve option mechanism increases consumer loans by $0.6917 \%$. 